\title{
A Study on Clinical Efficacy of Nagaradi Modak in the Management of Arsha W.S.R to Piles
}

\author{
Research Article
}

\author{
Anant Kumar V. Shekokar ${ }^{1^{*}}$, Kanchan M. Borkar ${ }^{2,}$ Pratik P Raut $^{3}$ \\ 1. Reader \& HOD, 2. Lecturer, 3. PG Scholar \\ Dept. of Shalya-Tantra, SVNH Ayurved College, Rahuri
}

\begin{abstract}
According to Indian Journal of Surgery among two Thousand consecutive proctologic examinations $75 \%$ incidence of Piles was found. About $50 \%$ of population of the world above 50 years aged people suffering from piles, hence the present study has been carried out to study efficacy of Nagaradi Modak. 40 patients were selected according to age, sex, inclusive \& exclusive criteria in a single group. The Nagaradi Modak was given in the form of capsule, 2 caps of $500 \mathrm{mg}$ each of Nagaradi Modak given in the pratah kala (Morning) with sheeta jala for 4 weeks. Patients were followed once in a week for 4 weeks, in which shula prashaman, raktastmbham, vibhanda, deepan, pachan action of drug observed. The results were statistically analyzed and the results have shown that Nagaradi Modak therapy is effective in the management of Arsha.
\end{abstract}

\section{Keywords:} Vibhandha

Piles, Nagaradi Modak, Arsha, Deepana, Shula Prashamana, Raktastambhaka,

\section{Introduction:}

During process of pathogenesis, the Doshas are vitiated due to indulgence in etiological factors by the person and that in turn leads to Agnimandya which further hampers the function of Apana vayu, vitiated Apana vayu leads to collection of faeces in guda vali and eventually vitiates the other vayu and doshas, these vitiated doshas get localized in the mamsam of guda pradesha which results into appearance of mansamprarohas or Arsha (Piles). (1)

Acharya sushruta Describes four

*Corresponding Author:

Anant Kumar V Shekokar,

Department of Shalya Tantra,

Ayurved College, Rahuri. 413706

Maharasrta, India

Email: dranantkumarshekokar@gmail.com Ph.No: +91 9860376534 principle therapeutic measures in management of Arshas i.e. Bhaishajya Chikitsa, Kshar karma, Agni karna \& Shastra karma.(2)

These measures in definite order are suggestive of similar methods to be preferred first. In spite of being primarily a surgeon, sushruta has laid maximum emphasis on unnecessary surgery.Bhaishajya Karma has no fear of complication like infection, gangrene and bleeding in comparsion of other modern surgical procedures. Nagaradi Modak is indicated for the treatment of arsha as oral medication in Bhaishajya Ratnavali and was selected for the present study.

\section{Aims \& Objectives:}

1) To study effect of Nagaradi Modak in the management of Arsha. 
2) To derive a standard, easily

palliative cure for Arsha accessible, cost effective and

Drug Review: Nagaradi Modak (4)

\begin{tabular}{|l|l|l|l|l|l|l|l|l|}
\hline $\begin{array}{l}\text { S } \\
\text { r. } \\
\text { N } \\
\text { o. }\end{array}$ & $\begin{array}{l}\text { Sansk } \\
\text { rit } \\
\text { Name }\end{array}$ & $\begin{array}{l}\text { Botanic } \\
\text { al } \\
\text { Name }\end{array}$ & Gana & Rasa & $\begin{array}{l}\text { Gun } \\
\text { a }\end{array}$ & $\begin{array}{l}\text { Vir } \\
\text { ya }\end{array}$ & Vipak & $\begin{array}{l}\text { Rogagh } \\
\text { nata }\end{array}$ \\
\hline 1 & $\begin{array}{l}\text { Nagar } \\
(5)\end{array}$ & $\begin{array}{l}\text { Zingibe } \\
\text { r) } \\
\text { Officina } \\
\text { le } \\
\text { Roscoe }\end{array}$ & $\begin{array}{l}\text { Deepan } \\
\text { iya } \\
\text { Shulpr } \\
\text { asha } \\
\text { Mana }\end{array}$ & Katu & $\begin{array}{l}\text { Lagh } \\
\text { u, } \\
\text { singd } \\
\text { ha }\end{array}$ & $\begin{array}{l}\text { Ush } \\
\text { na }\end{array}$ & $\begin{array}{l}\text { Madh } \\
\text { ura }\end{array}$ & $\begin{array}{l}\text { Arsha } \\
\text { Viband } \\
\text { ha }\end{array}$ \\
\hline 2 & $\begin{array}{l}\text { Bhalla } \\
\text { Taka } \\
(6)\end{array}$ & $\begin{array}{l}\text { Some } \\
\text { Carpus } \\
\text { Anacar } \\
\text { dium } \\
\text { Linn }\end{array}$ & $\begin{array}{l}\text { Deepan } \\
\text { iya }\end{array}$ & Katu & $\begin{array}{l}\text { Lagh } \\
\text { u, } \\
\text { singd } \\
\text { ha }\end{array}$ & $\begin{array}{l}\text { Ush } \\
\text { na }\end{array}$ & $\begin{array}{l}\text { Madh } \\
\text { ura }\end{array}$ & $\begin{array}{l}\text { Arsha, } \\
\text { Shotha. }\end{array}$ \\
\hline 3 & $\begin{array}{l}\text { Vrid } \\
\text { hadar } \\
\text { uka } \\
(7)\end{array}$ & $\begin{array}{l}\text { Aegyrei } \\
\text { a } \\
\text { Specios } \\
\text { a Sweet }\end{array}$ & Pachak & Katu & $\begin{array}{l}\text { Lagh } \\
\text { u, } \\
\text { singd } \\
\text { ha }\end{array}$ & $\begin{array}{l}\text { Ush } \\
\text { na }\end{array}$ & $\begin{array}{l}\text { Madh } \\
\text { ura }\end{array}$ & $\begin{array}{l}\text { Anulom } \\
\text { ak, }\end{array}$ \\
\hline 4 & $\begin{array}{l}\text { Guda } \\
\text { 8) }\end{array}$ & $\begin{array}{l}\text { Jaggery } \\
\text { Shothag } \\
\text { hna }\end{array}$ \\
\hline
\end{tabular}

Materials \& Methods: In The Present Study Nagaradi Modak prepared with above drugs formulation

$\begin{array}{ll}\text { Shunthi } & 1 \text { Part } \\ \text { Bhallatak } & 1 \text { Part } \\ \text { Vridhadaruka } & 1 \text { Part } \\ \text { Guda } & 2 \text { Part }\end{array}$

All above drugs are mixed and manually filled in capsule; weight of each capsule is $500 \mathrm{mg}$. The preparation of drug has been carried out in the Shalya tantra department \& drug standardization was done research laboratory of Ayurved college Rahuri.

\begin{tabular}{|l|l|}
\hline Kala & Prataha (morning) \\
\hline Dose & $\begin{array}{l}2 \\
\text { Capsule/Day(1gm) }\end{array}$ \\
\hline Anupana & Sheet jal \\
\hline Form of Drugs & Capsule \\
\hline
\end{tabular}

\begin{tabular}{|l|l|}
\hline $\begin{array}{l}\text { Route of } \\
\text { Administration }\end{array}$ & Oral \\
\hline Duration & 4 week's \\
\hline Follow up & $\begin{array}{l}1 \text { in a week for } 30 \\
\text { Day's }\end{array}$ \\
\hline
\end{tabular}

\section{Clinical study:}

The study will be carried out in OPD \& IPD of Shalya-tantra dept. The patient attending OPD / IPD of Ayurved College, Rahuri were selected of their age, sex, religion, race, occupation etc., fulfilling the criteria of selection \& eligibility for study.

\section{Plan of Study:}

Prior to the commencement of the therapy in the selected patients, general information both of the patients and the disease were made as below.

A complete history of the disease along with complaints was recorded as per 
the specially prepared proforma for the Arsha (piles) with written consent of patient.

\section{Selection Criteria:-}

a) Eligilibility Criteria :-

i) Patient presenting with Nidan, Lakshana \& Samprapti of Arsha.

ii) Patient presenting with cause, clinical feature \& etiopathology of piles.

iii) Patient suffering from pile on local examination will be made both from Modern \& Ayurvedic line.

IV) A complete H/o disease along with complaints.

b) In the entire patient general, systemic, \& local examination will be carried out. The finding of local examination will be studied under the following heading.

1 Inspection. 3

Palpation.

2 Digital examination 4

Proctoscopy

C) Laboratory investigations:

1) Blood investigations - Routine

blood, blood sugar.H1H2 if required.
2) Bleeding time and clotting time.

3) Stool and urine pathological examination of microscopic and routine

\section{Exclusion Criteria:-}

a) Ca Anus \& Rectum. g) Ulcerative colitis

b) Perianal Abscess. $\quad$ h) Proctitis

c) Piles (Arsha) with Fissure i) Rectal Polyp

d) Piles (Arsha) with Fistula j) Condyloma

e) Prolapsed Rectum kn Anal epithelioma

f) Chron's disease 1) Patient with any associated disease e.g. DM, HT.

Result obtained from the study will be assessed in the terms of:-

Incurable

Below $\quad 25 \%$

Improved $25 \%$ to $50 \%$

Markedly improved - $\quad 51 \%$ to $75 \%$

Cured

More than $75 \%$

Criteria of Assessment

\begin{tabular}{|l|l|l|l|l|l|l|}
\hline $\begin{array}{l}\text { Sr. } \\
\text { No. }\end{array}$ & Symptoms & Absent & Mild & Moderate & Severe & Markedly Severe \\
\hline 1 & Gudashula & 0 & 1 & 2 & 3 & 4 \\
\hline 2 & Gudadaha & 0 & 1 & 2 & 3 & 4 \\
\hline 3 & Kandu & 0 & 1 & 2 & 3 & 4 \\
\hline 4 & Raktasrava & 0 & 1 & 2 & 3 & 4 \\
\hline 5 & Bhransha & 0 & 1 & 2 & 3 & 4 \\
\hline 6 & Sparsha asahatva & 0 & 1 & 2 & 3 & 4 \\
\hline 7 & Shotha & 0 & 1 & 2 & 3 & 4 \\
\hline 8 & Mucons Discharge & 0 & 1 & 2 & 3 & 4 \\
\hline 9 & Vibandha & 0 & 1 & 2 & 3 & 4 \\
\hline 10 & Agnivaishamya & 0 & 1 & 2 & 3 & 4 \\
\hline 12 & Pandu & 0 & 1 & 2 & 3 & 4 \\
\hline
\end{tabular}

Observation \& Results:

The above said subjective parameters of the study were recorded without any bias $\&$ the obtained result were tabulated \& the results are assessed statistically by using paired $\mathrm{t}$ test which are expressed in terms of $t$ value at $5 \%$ to shows the significance of the study. 
Effect of Therapy on Cardinal Symptoms of Arsha

\begin{tabular}{|l|l|l|l|l|l|l|l|l|l|}
\hline $\begin{array}{l}\text { Sign } \\
\text { Symptoms }\end{array}$ & N & $\begin{array}{l}\text { Mean } \\
\text { B.T. }\end{array}$ & $\begin{array}{l}\text { mean } \\
\text { A.T. }\end{array}$ & $\begin{array}{l}\text { BT } \\
\text { SD }\end{array}$ & $\begin{array}{l}\text { AT } \\
\text { SD }\end{array}$ & $\begin{array}{l}\text { t } \\
\text { Value }\end{array}$ & $\begin{array}{l}\text { P } \\
\text { value }\end{array}$ & Result & $\begin{array}{l}\% \\
\text { Relief }\end{array}$ \\
\hline Guda Shula & 22 & 1.64 & 0.14 & 0.65 & 0.35 & 9.53 & 0.0001 & H.S & $91 \%$ \\
\hline Gudadaha & 18 & 1.89 & 0.17 & 0.60 & 0.38 & 10.27 & 0.0001 & H.S & $86 \%$ \\
\hline Guda srava & 10 & 1.50 & 0.20 & 0.70 & 0.42 & 5.03 & 0.0001 & H.S & $83 \%$ \\
\hline Rakta srava & 11 & 1.45 & 0.36 & 0.68 & 0.67 & 3.787 & 0.0012 & S & $75 \%$ \\
\hline $\begin{array}{l}\text { Agni Vai } \\
\text { shmya }\end{array}$ & 28 & 1.79 & 0.39 & 0.83 & 0.49 & 7.686 & 0.0001 & N.S & $78 \%$ \\
\hline Bhramsha & 30 & 1.37 & 1.23 & 0.49 & 0.50 & 1.095 & 0.2779 & N.S & $9 \%$ \\
\hline Vibandha & 29 & 1.72 & 0.62 & 0.75 & 0.56 & 6.33 & 0.0001 & H.S & $64 \%$ \\
\hline Sparsh asahtva & 27 & 1.59 & 0.48 & 0.74 & 0.50 & 6.458 & 0.0001 & H.S & $69 \%$ \\
\hline Kandu & 11 & 1.61 & 0.36 & 0.67 & 0.50 & 4.959 & 0.0001 & H.S & $62 \%$ \\
\hline Pandu & 11 & 1.73 & 0.82 & 0.64 & 0.40 & 3.999 & 0.0007 & H.S & $52 \%$ \\
\hline Shotha & 21 & 1.29 & 0.38 & 0.46 & 0.49 & 6.205 & 0.0001 & H.S & $70 \%$ \\
\hline
\end{tabular}

$\mathrm{N}=$ number of patients, S.D $=$ Standard Deviation, B.T. $=$ Before Treatment, AT $=$ After Treatment, $\%=$ Percentage, $\mathrm{Cal}=$ Calculated, $\mathrm{HS}=$ Highly Significant, $\mathrm{S}=$ Significant, NS $=$ Not significant

Overall effect of Therapy:

\begin{tabular}{|l|l|l|}
\hline Result & No of Pt & Percentage \\
\hline Cured & 12 & $30 \%$ \\
\hline Markedly Improved & 23 & $57 \%$ \\
\hline Improved & 05 & $12.5 \%$ \\
\hline Unchanged & 0 & 0 \\
\hline
\end{tabular}

\section{Discussion:}

Nagaradi Modak has revealed to have potential of shula prashamana and disease modifying effect with the added advantage of being free from side effects, gastric irritation and ulcerogenic activity. Almost all the symptoms studied have shown highly significant results $\&$ almost above $60 \%$ of the relief in the symptoms except for the symptoms like bramsha.

In Nagaradi Modak Formulation the ingredients are Ushna.Tikshana and snigdha properties may correct the vata dushi \& regulate the function of Apana Vayu which breaks samprati \& cures the disease arsha .These above mentioned properties also helps in vata anuloman so vibandha is also relived.

Shunthi, Bhallataka \& Vriddhadaruka all these drugs are katu, tikta, Kashaya Rastmaka, Madhurvipaki
\& stambhana property has shown significant relief in Raktastrav.

\section{Conclusion:}

Nagaradi Modak is shula Prashamen (Pain reliever), Aam pachaka so it gives quick effect \& can be permanent cure for Arsha.

In the persent study little modification regarding form of drug has been made such as the drug is prepared as per classics but the contents are filled in capsule such capsules are well known to society $\&$ pass modern standardization process \&also convenient to consume bitter test drugs.(9)

Lastly Administration of capsule Nagardi Modak orally is easy \& does not require any surgical skills or special instrumental aid and convenient to patient \& has minimum interference in patient's day to day activities. 


\section{References:}

1) Kaviraj Sushruta samhita of Acharua sushruta with Ayurvedatatva sandipika commentary, Chaukhamba Sanskrit sansthan, $13^{\text {th }}$ edition, Varanasi, 2002, $237 \mathrm{P}$.

2) Kaviraj Ambikadatta Shastri, Sushruta samhita of Acharua sushruta with Ayurvedatatva sandipika commentary, Chaukhamba Sanskrit sansthan, $13^{\text {th }}$ edition, Varanasi, 2002, 35 P.

3) Kaviraj Ambikadatta Shastri, Bhaisajya Ratanavati, $15^{\text {th }}$ edition, Varanasi, 2002, 217 P.

4) Kaviraj Ambikadatta Shastri, Bhaisajya Ratanavati, $15^{\text {th }}$ edition, Varanasi, 2002, 217 P.
5) .Bramhashankar shastri, bhavprakash Nighantu, $6^{\text {th }}$ edition, Varanasi, Chaukhamba Sanskrut Bhavan 1994, 12,13,14 P

6) Bramhashankar shastri, bhavprakash Nighantu, $6^{\text {th }}$ edition, Varanasi, Chaukhamba Sanskrut Bhavan 1994, 138-141 P.

7) Bramhashankar shastri, bhavprakash Nighantu, $6^{\text {th }}$ edition, Varanasi, Chaukhamba Sanskrut Bhavan 1994, 409 P.

8) Bramhashankar shastri, bhavprakash Nighantu, $6^{\text {th }}$ edition, Varanasi, Chaukhamba Sanskrut Bhavan 1994, 795-796 P.

9) Dr. Pratik P Raut, A Study of Nagaradi Modak in the management of arsha w.s.r.to piles, 2011,M.U.H.S.Nashik,190 P. 